\title{
PENGARUH WADAH; SUHU DAN WAKTU SIMPAN TERHADAP PERKECAMBAHAN BENIH MENIRAN (Phyllanthus niruri L.)
}

\section{The Effect of Storage Container, Temperature and Time on Meniran (Phyllanthus niruri L.) Seed Germination}

\author{
Nurul Husniyati Listyana1), Rahma Widyastuti1), Widyantoro ${ }^{1)}$ \\ Balai Besar Penelitian dan Pengembangan Tanaman Obat dan Obat Tradisional \\ Jalan Raya Lawu No 11 Tawangmangu \\ Email: nurul.haydar@gmail.com
}

\begin{abstract}
Meniran (Phyllanthus niruri L.) is a wild plant that used extensively as a raw material for traditional medicine but has not been cultivated yet. Meniran cultivation requires the availability of quality seeds and seedlings to produce the high productivity. The ability of seeds to germinate (seed viability) after the storage period is influenced by several factors both internal and external, including seed water content, genetic traits, initial viability and packaging material, storage temperature and humidity, microorganisms, and human factors. The study aimed to determine the effect of storage containers, storage temperature and time of storage on the power of meniran seed germination. The study was conducted in March-April 2018 at the B2P2TO2T Seed Laboratory. The research design was Factorial Completely Randomized Design with 3 factors and 3 replications. The first factor was a storage container consisting of plastic, paper envelopes and aluminum foil. Second factor was a storage temperature consisting of $0^{\circ} \mathrm{C},-20^{\circ} \mathrm{C}$ and $-50^{\circ} \mathrm{C}$. The third factor was storage time which consists of 2 weeks, 4 weeks, 6 weeks, 8 weeks and 10 weeks. The results showed that the storage container and storage time had a significantly different effect on meniran seed germination. The storage time did not have a significant effect on germination. Together, the storage container, storage temperature and storage time did not have a significant effect on meniran seed germination. The interaction between the storage temperature and the storage time and the interaction between the storage container and the storage time gave significantly different effects on germination.
\end{abstract}

Keywords : meniran, storage container, storage temperature, storage time, germination

\begin{abstract}
ABSTRAK
Meniran (Phyllanthus niruri L.) merupakan tanaman yang simplisianya banyak dibutuhkan sebagai bahan baku obat tradisional namun belum dibudidayakan. Budidaya tanaman meniran memerlukan ketersediaan benih dan bibit yang bermutu untuk menghasilkan produktivitas yang tinggi. Kemampuan benih untuk berkecambah (viabilitas benih) setelah masa penyimpanan dipengaruhi oleh beberapa faktor baik internal maupun eksternal, meliputi kadar air benih, sifat genetik, viabilitas awal serta bahan pengemas, suhu dan kelembaban ruang simpan, mikroorganisme, serta faktor manusia. Penelitian bertujuan untuk mengetahui pengaruh wadah simpan, suhu simpan dan waktu simpan terhadap daya perkecambahan benih meniran. Penelitian dilaksanakan pada bulan Maret-April 2018 di Laboratorium Benih B2P2T02T. Desain penelitian yang digunakan yaitu Rancangan Acak Lengkap Faktorial dengan 3 faktor dan 3 ulangan. Faktor 1 yaitu wadah penyimpanan yang terdiri dari plastik, kertas amplop dan aluminium foil. Faktor 2 yaitu suhu simpan yang terdiri dari $0^{\circ} \mathrm{C},-20^{\circ} \mathrm{C}$ dan $-50^{\circ} \mathrm{C}$. Faktor 3 yaitu waktu penyimpanan yang terdiri dari 2 minggu, 4 minggu, 6 minggu, 8 minggu dan 10 minggu. Hasil penelitian menunjukkan wadah simpan dan waktu simpan memberikan pengaruh yang berbeda signifikan terhadap perkecambahan benih meniran. Suhu simpan tidak memberikan pengaruh yang berbeda signifikan terhadap perkecambahan. Secara bersama-sama wadah simpan, suhu simpan dan waktu simpan tidak memberikan pengaruh yang berbeda signifikan terhadap perkecambahan benih meniran. Interaksi antara suhu simpan dan waktu simpan serta interaksi antara wadah simpan dan waktu simpan memberikan pengaruh yang berbeda signifikan terhadap perkecambahan.
\end{abstract}


Kata kunci : meniran, wadah simpan, suhu simpan, waktu simpan, perkecambahan

\section{PENDAHULUAN}

Meniran (Phyllanthus niruri L.) sejauh ini dikenal sebagai tanaman liar (gulma) yang banyak terdapat di ladang-ladang, tanah berbatu dan hutan yang lembab. Tumbuh tersebar pada ketinggian antara $1 \mathrm{~m}$ sampai $1000 \mathrm{~m}$ dpl, di tempat terbuka, pada tanah gembur yang mengandung pasir, ladang, tepi sungai dan pantai (Widiyastuti, dkk., 2012).

Meniran mengandung alkaloid, flavonoid (Rivai, dkk. 2013), saponin, tanin (Mangunwardoyo, dkk. 2009), fenol, kumarin, terpenoid, dan lignan (filantin dan hipofilantin) (Alegantina, et al., 2015). Meskipun termasuk tanaman liar, namun tanaman ini memiliki banyak khasiat. Khasiat meniran yang paling terkenal yaitu mampu meningkatkan sistem kekebalan tubuh (Tjandrawinata, et al., 2017), di samping itu juga mempunyai efek antihiperurisemia (Nurihardiyanti, 2017), dapat memperbaiki kerusakan sel $\beta$-pankreas dan menurunkan kadar glukosa darah (Wahjuni, 2017; Nugrahani, 2013) serta membantu menyembuhkan luka sayat (Himawan, et al., 2017).

Berdasarkan data BPS tahun 2015, meniran (P. niruri) termasuk ke dalam 12 jenis tanaman obat yang digunakan dalam industri obat tradisional. Volume meniran yang digunakan dalam industri obat tradisional tercatat sebesar 5,496 kg dengan nilai transaksi sebesar Rp. 21.986.000,00 (Badan Pusat Statistik, 2015). Meskipun kebutuhan meniran untuk industri obat tradisional termasuk tinggi, namun tanaman ini belum dibudidayakan, sehingga belum tersedia informasi yang memadai mengenai budidaya meniran. Budidaya merupakan satu-satunya cara agar diperoleh kualitas bahan yang terstandar. Proses budidaya yang terstandar diawali dengan ketersediaan bibit yang berkualitas. Bibit dapat diperoleh dengan cara generatif dan vegetatif. Secara generatif, bibit yang digunakan dalam kegiatan budidaya diperoleh dari benih.

Benih memegang peranan yang sangat penting dalam budidaya. Benih bersama sarana produksi lainnya ikut menentukan kualitas hasil tanaman. Benih yang bermutu tidak dapat dihasilkan tanpa melaksanakan sistem produksi yang baik dan berkualitas di setiap tahapannya. Benih bermutu tinggi dihasilkan melalui proses budidaya tanaman sumber benih (seed crop), pengolahan benih, penyimpanan benih sampai distribusinya (Mugnisjah, 2008). Tanaman meniran merupakan salah satu jenis tanaman semusim yang diperbanyak secara generatif atau menggunakan benih sebagai sumber bibit. Untuk mencukupi permintaan yang besar diperlukan kontinuitas dalam penyediaan bahan. Artinya diperlukan juga kontinuitas dalam penyediaan benih sebagai bahan bibit untuk kegiatan budidaya meniran. Untuk menjaga kontinuitas benih diperlukan suatu perlakuan penyimpanan agar benih yang tersedia terjaga kualitasnya. Benih meniran termasuk ke dalam golongan benih ortodoks. Benih ortodoks adalah benih yang pada saat panen/masak fisiologi memiliki kandungan kadar air yang relatif rendah. Benih ortodoks akan tetap hidup meski mempunyai kadar air yang rendah (2\%-5\%). Pada kadar air yang rendah benih ortodoks mampu disimpan pada suhu dingin dalam jangka waktu yang lama. (Sahupala, 2010).

Kemampuan benih untuk berkecambah (viabilitas benih) setelah masa penyimpanan dipengaruhi oleh beberapa faktor. Faktor-faktor yang mempengaruhi viabilitas benih selama penyimpanan meliputi, faktor internal yaitu kadar air, sifat genetik, viabilitas awal dan faktor eksternal yaitu suhu dan kelembaban ruang simpan, kemasan, mikroorganisme, dan manusia (Paramita, et al., 2018). Kadar air dalam ruang penyimpanan yang lebih tinggi dibandingkan kadar air pada benih dapat menyebabkan terjadinya perubahan kadar air benih dalam 
penyimpanan. Berdasarkan hal tersebut dibutuhkan bahan pengemas yang mampu mencegah bertambahnya kadar air benih dalam penyimpanan (Kuswanto, 2003).

Benih meniran meskipun merupakan benih ortodok yang tidak mati walau disimpan lama, namun viabilitasnya perlu diuji, karena viabilitas benih secara alami akan menurun seiring lamanya penyimpanan (Febriyanti \& Surahman, 2015). Untuk mempertahankan kualitas selama penyimpanan, benih harus disimpan dalam wadah dan suhu tertentu (BHP UMY, 2010). Menurut (Suita, 2013) pada waktu penyimpanan 2 minggu viabilitas tertingggi ditunjukkan oleh benih kilemo yang disimpan menggunakan kain belacu dan berada di suhu kamar. Sedangkan untuk jangka waktu penimpanan yang lebih lama sebaiknya menggunakan wadah plastik dan disimpan di suhu kulkas $\left(8-12^{\circ} \mathrm{C}\right)$. Menurut (Yuniarti \& Djaman, 2015) tujuan penyimpanan benih adalah diperolehnya ketersediaan benih yang berdaya hidup tinggi dalam jangka waktu tertentu hingga saatnya diperlukan untuk penanaman. Sehubungan dengan hal tersebut dipandang perlu untuk dilakukan penelitian yang bertujuan untuk mengetahui pengaruh wadah simpan, suhu simpan dan waktu simpan terhadap perkecambahan benih meniran.

\section{METODE}

Penelitian dilaksanakan mulai bulan Maret-April 2018 bertempat di Laboratorium Benih Balai Besar Penelitian dan Pengembangan Tanaman Obat dan Obat Tradisional Tawangmangu. Penelitian ini bersifat eksperimental dengan desain penelitian Rancangan Acak Lengkap Faktorial dengan 3 faktor dan 3 kali ulangan. Faktor pertama yaitu wadah penyimpanan yang terdiri dari plastik klip, kertas amplop dan aluminium foil. Faktor kedua yaitu suhu simpan yang terdiri dari $0^{\circ} \mathrm{C},-20^{\circ} \mathrm{C}$ dan $-50^{\circ} \mathrm{C}$. Menurut Widodo, dkk (2010) benih yang disimpan pada suhu dingin mampu mempertahankan daya kecambahnya dibandingkan benih yang disimpan pada suhu ruang. Faktor ketiga yaitu waktu penyimpanan yang terdiri atas 2, 4, 6, 8 dan 10 minggu (Kolo \& Tefa, 2016). Sebagai kontrol digunakan meniran yang belum mengalami perlakuan penyimpanan.

Benih yang digunakan dalam penelitian berasal dari kebun percobaan Toh Kuning, Kecamatan Karangpandan, Karanganyar. Benih dikelompokkan berdasarkan masing-masing perlakuan. Benih dikemas sesuai kelompok perlakuan dan ulangan, masing-masing sebanyak 25 benih setiap kemasan. Setiap perlakuan dilakukan 3 kali ulangan. Benih yang diamati disebar pada cawan petri yang sudah dialasi kertas tisu dan disemprot air hingga lembab.

Data yang diamati yaitu jumlah benih yang berkecambah selama rentang waktu pengamatan yaitu selama 10 hari. Pengamatan dilakukan secara destruktif yaitu benih yang berkecambah dicabut dan dibuang. Jumlah benih yang berkecambah dicatat setiap hari dan dijumlahkan pada akhir waktu pengamatan. Data hasil pengamatan dianalisis menggunakan Univariate Analysis of Variance. Apabila terdapat beda nyata dan untuk melihat pengaruh masing-masing perlakuan dilanjutkan dengan analisis Duncan Multiple Range Test dengan taraf kesalahan $5 \%$.

\section{HASIL DAN PEMBAHASAN}

Penelitian ini bertujuan untuk mengevaluasi pengaruh jenis wadah penyimpanan benih yang disimpan pada suhu dan waktu yang bervariasi. Pada penyimpanan 2 minggu total benih yang berkecambah untuk semua jenis wadah dan suhu simpan menunjukkan angka yang relatif sama berkisar antara $27-39 \%$ benih yang berkecambah. Pada masa penyimpanan 4 minggu jumlah benih yang berkecambah paling banyak ditunjukkan oleh kelompok benih yang disimpan 
pada suhu $-50^{\circ} \mathrm{C}$ dengan wadah plastik. Pada masa penyimpanan 6 minggu daya berkecambah paling banyak ditunjukkan oleh benih yang disimpan pada suhu $-50^{\circ} \mathrm{C}$ dengan wadah plastik. Pada masa penyimpanan 8 minggu jumlah benih yang berkecambah paling banyak ditunjukkan oleh kelompok benih yang disimpan pada suhu $-50^{\circ} \mathrm{C}$ pada wadah aluminium. Demikian juga pada masa penyimpanan 10 minggu jumlah benih yang paling banyak berkecambah ditunjukkan pada kelompok benih yang disimpan pada wadah aluminium pada suhu $-50^{\circ} \mathrm{C}$ (Gambar 1 ).

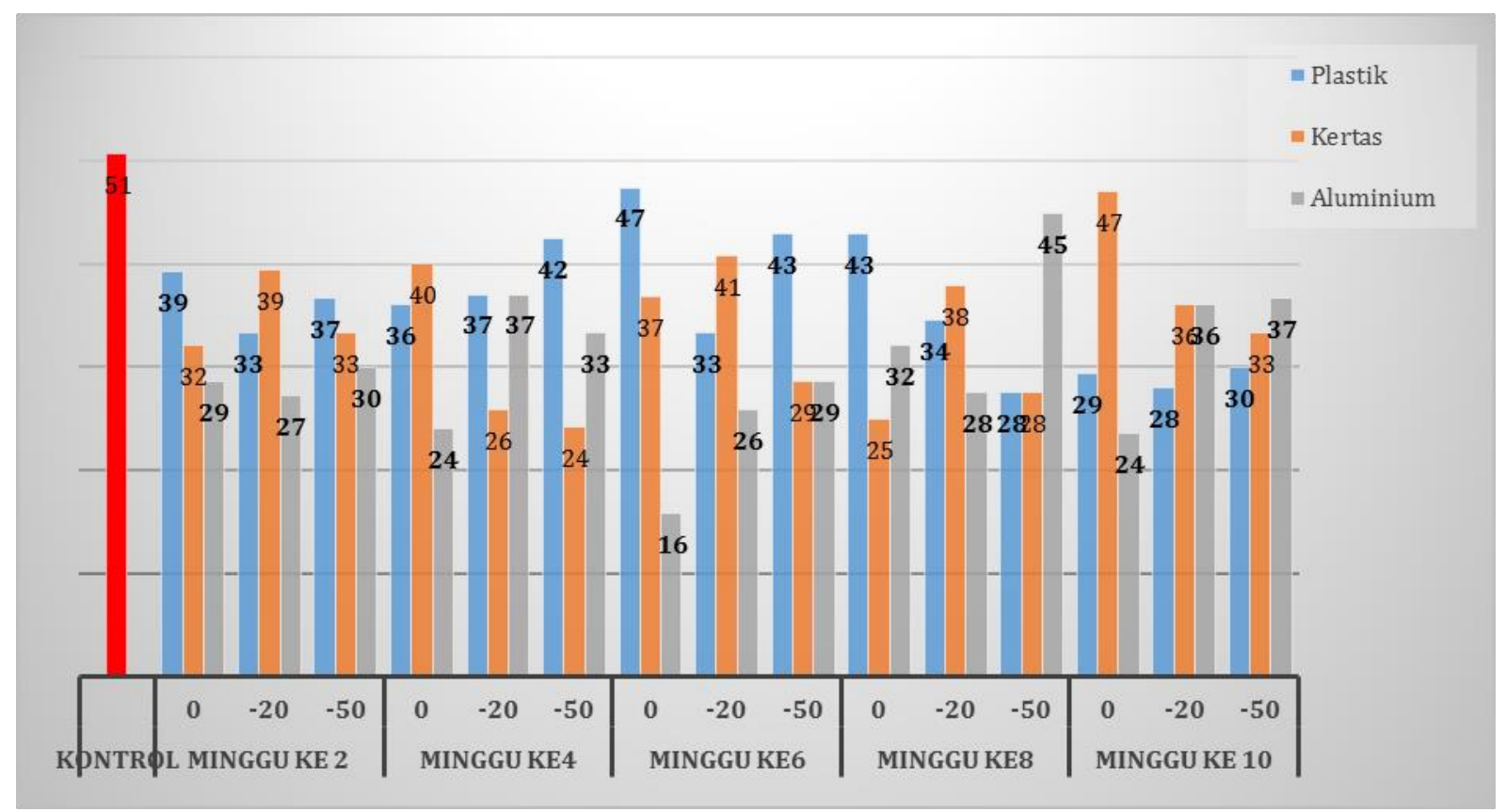

Gambar 1. Grafik Total Persentase Perkecambahan Benih Meniran dengan Berbagai Perlakuan Keterangan: data diambil dari jumlah rerata 3 ulangan yang dilakukan secara destruktif sample setiap tahapan waktu penyimpanan.

Jumlah benih yang berkecambah berfluktuasi dari waktu ke waktu. Hal ini kemungkinan disebabkan oleh wadah yang berbeda-beda untuk setiap kelompok meskipun jenis bahan yang digunakan sama. Suhu ruang penyimpanan benih sangat berpengaruh terhadap laju deteriorasi. Semakin rendah suhu penyimpanan, benih akan bertahan lebih lama ketika disimpan. Semakin tinggi suhu penyimpanan benih, maka benih akan mengalami perombakan cadangan makanan yang menyebabkan peningkatan respirasi dan menurunkan persentase perkecambahan (Kuswanto, 2003). Selanjutnya hasil analisis statistik pengaruh wadah (kemasan), suhu dan waktu penyimpanan terhadap perkecambahan benih meniran disampaikan pada Tabel 1.

Wadah simpan dan waktu simpan memberikan pengaruh yang signifikan terhadap perkecambahan benih (Tabel 1). Sedangkan suhu simpan tidak memberikan pengaruh yang signifikan. Secara bersamaan, hasil interaksi antara suhu simpan, wadah simpan dan waktu simpan tidak memberikan pengaruh yang signifikan terhadap perkecambahan benih meniran. Interaksi antara suhu simpan dan wadah simpan secara bersama-sama tidak memberikan pengaruh yang signifikan terhadap perkecambahan benih meniran. Interaksi suhu simpan dan waktu simpan secara bersama-sama memberikan pengaruh yang signifikan terhadap perkecambahan benih meniran. Demikian juga interaksi antara wadah simpan dan waktu simpan secara bersama-sama memberikan pengaruh yang signifikan terhadap perkecambahan benih meniran. Menurut Rahayu \& Eny, (2007) wadah simpan, waktu simpan dan jenis kemasan memberikan pengaruh terhadap perkecambahan benih. 
Tabel 1. Pengaruh suhu simpan, wadah simpan dan waktu simpan terhadap perkecambahan benih meniran

\begin{tabular}{lll}
\hline & Ftabel & Signifikansi \\
\hline Suhu simpan & 1,120 & $0,331^{\text {ns }}$ \\
Wadah simpan & 6,422 & $0,002^{*}$ \\
Waktu simpan & 2,827 & $0,029^{*}$ \\
Suhu simpan*Wadah simpan & 2,224 & $0,073^{\text {ns }}$ \\
Suhu simpan*Waktu simpan & 2,318 & $0,026^{*}$ \\
Wadah simpan*Waktu simpan & 2,330 & $0,025^{*}$ \\
Suhu simpan*Wadah simpan*Waktu simpan & 1,669 & $0,067^{\text {ns }}$ \\
\hline
\end{tabular}

Keterangan: * = berbeda nyata

ns= tidak berbeda nyata

Tabel 2. Persentase perkecambahan benih meniran pada berbagai suhu dan waktu penyimpanan

\begin{tabular}{cccccc}
\hline \multirow{2}{*}{ Suhu $\left({ }^{\circ} \mathrm{C}\right)$} & \multicolumn{5}{c}{ Persentase Perkecambahan pada Minggu ke- } \\
\cline { 2 - 6 } & 2 & 4 & 6 & 8 & 10 \\
\hline 0 & $44,00^{\mathrm{g}}$ & $38,84^{\mathrm{de}}$ & $32,68^{\mathrm{a}}$ & $42,00^{\mathrm{efg}}$ & $33,20^{\mathrm{ab}}$ \\
-20 & $43,12^{\mathrm{efg}}$ & $33,32^{\mathrm{ab}}$ & $40,68^{\mathrm{ef}}$ & $43,32^{\mathrm{efg}}$ & $40,68^{\mathrm{ef}}$ \\
-50 & $35,12^{\mathrm{abc}}$ & $40,68^{\mathrm{ef}}$ & $40,68^{\mathrm{ef}}$ & $40,68^{\mathrm{ef}}$ & $37,32^{\mathrm{cd}}$ \\
\hline
\end{tabular}

Keterangan: angka-angka yang diikuti huruf berbeda menunjukkan ada beda nyata pada uji DMRT 0.05

Hasil analisis interaksi antara waktu simpan dan suhu simpan terhadap perkecambahan benih meniran kombinasi faktor waktu simpan 2 minggu dan suhu $0^{\circ} \mathrm{C}$ menunjukkan jumlah benih berkecambah yang nyata terbanyak dibandingkan interaksi lainnya. Menurut Solikin (2014) jumlah benih yang berkecambah awalnya rendah dan akan terus meningkat sampai pada kondisi optimum. Setelah tercapai kondisi optimum, jumlah benih yang berkecambah akan kembali menurun.

Tabel 3. Persentase perkecambahan benih meniran pada berbagai wadah dan waktu penyimpanan

\begin{tabular}{lccccc}
\hline \multirow{2}{*}{ Wadah Simpan } & \multicolumn{5}{c}{ Persentase Perkecambahan pada Minggu ke- } \\
\cline { 2 - 6 } & 2 & 4 & 6 & 8 & 10 \\
\hline Plastik & $37,76^{\mathrm{fg}}$ & $32,88^{\mathrm{cd}}$ & $40,88^{\mathrm{h}}$ & $40,00^{\mathrm{g}}$ & $36,00^{\mathrm{ef}}$ \\
Kertas & $44,44^{\mathrm{i}}$ & $36,00^{\text {ef }}$ & $35,12^{\mathrm{de}}$ & $44,00^{\mathrm{i}}$ & $38,24^{\mathrm{fg}}$ \\
Alumunium & $40,00 \mathrm{~g}$ & $40,00 \mathrm{~g}$ & $24,00^{\mathrm{b}}$ & $31,56^{\mathrm{c}}$ & $20,80^{\mathrm{a}}$ \\
\hline
\end{tabular}

Keterangan: angka-angka yang diikuti huruf berbeda menunjukkan ada beda nyata pada uji DMRT 0.05

Benih meniran yang disimpan pada kombinasi perlakuan waktu simpan 10 minggu pada wadah aluminium menunjukkan jumlah benih berkecambah terendah dibandingkan kombinasi perlakuan lainnya. Hal ini bertolak belakang dengan hasil penelitian (Agustin, 2011) yang menyatakan bahwa aluminium foil mampu mempertahankan daya berkecambah benih. Kombinasi perlakuan wadah simpan kertas pada umur simpan 2 minggu menunjukkan jumlah benih berkecambah tertinggi namun tidak berbeda signifikan dengan umur simpan 8 minggu. Menurut Suryanto, (2013) kemasan kertas mempunyai pori yang besar sehingga memungkinkan benih menyerap dan melepas uap air ke udara. 
Tabel 4. Pengaruh wadah simpan terhadap perkecambahan benih meniran

\begin{tabular}{|c|c|}
\hline Jenis Kemasan & Jumlah Kecambah \\
\hline Aluminium & $9,78^{a}$ \\
\hline Plastik & $11,72^{\mathrm{b}}$ \\
\hline Kertas & $12,36^{b}$ \\
\hline
\end{tabular}

Benih yang disimpan pada wadah berbahan aluminium lebih sedikit berkecambah dibandingkan benih yang disimpan pada wadah plastik dan kertas (Tabel 4). Benih yang disimpan pada wadah aluminium menunjukkan total benih berkecambah yang berbeda nyata dibandingkan benih yang disimpan dalam wadah plastik dan kertas. Berdasarkan penelitian (Dinarto, 2010) wadah simpan berbahan plastik merupakan yang terbaik untuk menyimpan benih kacang hijau. Demikian juga pada benih kedelai, wadah simpan berupa kantong plastik memberikan pengaruh yang paling baik terhadap perkecambahan benih (Indartono, 2011).

Tabel 5. Pengaruh suhu simpan terhadap perkecambahan benih meniran

\begin{tabular}{cc}
\hline Suhu Simpan & Jumlah Kecambah \\
\hline $0^{\circ} \mathrm{C}$ & $8,5111^{\mathrm{a}}$ \\
$-20^{\circ} \mathrm{C}$ & $9,2667^{\mathrm{a}}$ \\
$-50^{\circ} \mathrm{C}$ & $9,3111^{\mathrm{a}}$ \\
\hline
\end{tabular}

Keterangan: angka-angka yang diikuti huruf berbeda pada kolom yang sama menunjukkan beda nyata pada uji DMRT 0.05

Jumlah benih meniran yang berkecambah pada berbagai suhu simpan relatif sama (Tabel 5). Berdasarkan hasil analisis yang telah dilakukan, suhu simpan tidak memberikan pengaruh yang signifikan terhadap perkecambahan benih meniran. Hal ini didukung dengan penelitian (Indartono, 2011) yang menyatakan bahwa suhu penyimpanan tidak berpengaruh nyata terhadap perkecambahan benih kedelai. Sedangkan berdasarkan penelitian (Nurisma, dkk., 2015) dinyatakan bahwa penyimpanan benih pada suhu rendah mampu mempertahankan daya berkecambah benih. Penyimpanan benih pada suhu yang lebih tinggi memicu terjadinya respirasi pada benih sehingga dapat menurunkan daya kecambah. Berdasarkan penelitian (Sahupala, 2010) suhu penyimpanan tidak memberikan pengaruh yang nyata terhadap viabilitas benih ortodoks.

Tabel 6. Pengaruh waktu simpan terhadap perkecambahan benih meniran

\begin{tabular}{cl}
\hline Waktu Simpan & \multicolumn{1}{c}{ Jumlah Kecambah } \\
\hline 2 minggu & $10,18^{\mathrm{c}}$ \\
4 minggu & $9,07^{\mathrm{abc}}$ \\
6 minggu & $8,33^{\mathrm{ab}}$ \\
8 minggu & $9,63^{\mathrm{bc}}$ \\
10 minggu & $7,93^{\mathrm{a}}$ \\
\hline
\end{tabular}

Keterangan: angka-angka yang diikuti huruf berbeda pada kolom yang sama menunjukkan beda nyata pada uji DMRT 0.05

Waktu simpan 2 minggu menunjukkan angka total benih berkecambah tertinggi dibandingkan dengan waktu simpan lainnya (Tabel 6). Daya kecambah menurun pada waktu simpan 4 minggu dan 6 minggu. Namun pada waktu simpan 8 minggu daya kecambah benih semakin meningkat. Pada waktu simpan 10 minggu daya kecambah benih kembali mengalami 
penurunan. Waktu simpan 2 minggu dan 10 minggu menunjukkan perbedaan yang signifikan dibandingkan waktu penyimpanan 4, 6 dan 8 minggu yang tidak menunjukkan perbedaan yang signifikan. Menurut (Fauziah \& Ramlah, 2013) daya berkecambah akan menurun seiring dengan bertambahnya waktu simpan.

\section{KESIMPULAN}

Berdasarkan hasil penelitian dapat disimpulkan bahwa secara bersama-sama interaksi antara suhu simpan, wadah simpan dan waktu simpan tidak memberikan pengaruh yang berbeda signifikan terhadap perkecambahan benih meniran. Secara parsial, waktu simpan dan wadah simpan memberikan pengaruh yang berbeda signifikan terhadap perkecambahan benih meniran. Sedangkan suhu simpan tidak memberikan pengaruh yang berbeda signifikan. Interaksi antara suhu simpan dan waktu simpan serta interaksi antara wadah simpan dan waktu simpan memberikan pengaruh yang berbeda signifikan terhadap perkecambahan.

\section{DAFTAR PUSTAKA}

Agustin, E. (2011). Pengaruh Metode Penyimpanan Terhadap Perkecambahan Biji Garcinia dulcis (Roxb.) Kurz. Berkalahayati Penelitian Hayati Edisi Khusus, Volume 7A, 99-101.

Alegantina, S., Setyorini, H. A. \& Triwahyuni. (2015). Pengujian Mutu Dan Penetapan Kadar Filantin Pada Ekstrak Etanol Herba Meniran (Phyllanthus Niruri Linn). Buletin Penelitian Kesehatan, 43(1), 11-16.

Badan Pusat Statistik. (2015). Statistik Industri Manufaktur Indonesia 2015. Jakarta: s.n.

BHP UMY. (2010). Penggunaan Benih Bermutu, Penting Bagi Peningkatan Produksi Pertanian. [Online] Available at: http://www.umy.ac.id/penggunaan-benih-bermutu-penting-bagipeningkatan-produksi-pertanian.html [Accessed 12 September 2018].

Dinarto, W. (2010). Pengaruh Kadar Air Dan Wadah Simpan Terhadap Viabilitas Benih Kacang Hijau dan Populasi Hama Kumbang Bubuk Kacang Hijau Callosobruchus chinensis L.. Jurnal Agri Sains, 1(1), 1-10.

Febriyanti, F. \& Surahman, M. (2015). Viabilitas Benih Koro (Canavalia ensiformis (L.) DC.) yang Disimpan pada Beberapa Jenis Kemasan dan Periode Simpan. Buletin Agrohorti, 15 Januari, 3(1), 119-126.

Himawan, H. C., Pramono \& Ayu, D. R. (2017). Uji Farmakologis Ekstrak Kental Daun Meniran (Phyllanthus niruri Linn) untuk Membantu Penyembuhan Luka Sayat pada Tikus Putih Jantan (Rattus norvegicus strain Sprague-Dawley). Farmamedika, Juni, 2(1), 25-32.

Indartono. (2011). Pengkajian Suhu Ruang Penyimpanan dan Teknik Pengemasan Terhadap Kualitas Benih Kedelai. Gema Teknologi, 16(3), 158-163.

Fauziah, K. \& Ramlah, A. (2013). Pengaruh Lama Penyimpanan Terhadap Kualitas Jagung Kuning dan Jagung Putih. Maros, Balai Penelitian Tanaman Serealia.

Kolo, E. \& Tefa, A. (2016). Pengaruh Kondisi Simpan Terhadap Viabilitas dan Vigor Benih Tomat (Lycopersicum esculentum, Mill). Savana Cendana, 1(3), 112-115.

Kuswanto, H. (2003). Teknologi Pemrosesan Pengemasan dan Penyimpanan Benih. Yogyakarta: Penerbit Kanisius.

Mangunwardoyo, W., Cahyaningsih, E. \& Usia, T. (2009). Ekstraksi dan Identifikasi Senyawa Antimikroba Herba Meniran (Phyllanthus niruri L.). Jurnal Ilmu Kefarmasian Indonesia, September.7(2). 
Mugnisjah, W. Q. (2008). Teknologi Benih. Jakarta: Universitas Terbuka.

Nugrahani, S. S. (2013). Analisis Perbandingan Efektifitas Ekstrak Akar, Batang, dan Daun Herba Meniran dalam Menurunkan Kadar Glukosa Darah Mencit. Unnes Journal of Public Health, 2(1), $1-9$.

Nurihardiyanti. (2017). Review Artikel: Aktifitas Antihiperurisemia Beberapa Tanaman Indonesia. Farmaka, Juni, 15(2), 11-22.

Nurisma, I. Agustyansyah \& Kamal, M., (2015). Pengaruh Jenis Kemasan dan Suhu Ruang Simpan terhadap Viabilitas Benih Sorgum (Sorghum bicolor [L.] Moench). Jurnal Penelitian Pertanian Terapan, 15(3), 183-190.

Paramita, K. E., Suharsi, T. K. \& Surahman, M. (2018). Optimasi Pengujian Daya Berkecambah dan Faktor yang Mempengaruhi Viabilitas dan Vigor Benih Kelor (Moringa oleifera Lam.) dalam Penyimpanan. Buletin Agrohorti, 6(2), 221-230.

Rahayu, E. \& Eny, W. (2007). Pengaruh Kemasan, Kondisi Ruang Simpan dan Periode Simpan terhadap Viabilitas Benih Caisin (Brassica chinensis L.). Buletin Agronomi, 35(3), 191-196.

Rivai, H., Septika, R. \& Boestari, A. (2013). Analisis Perbandingan Efektifitas Ekstrak Akar, Batang, dan Daun Herba Meniran dalam Menurunkan Kadar Glukosa Darah Mencit. Jurnal Farmasi Higea, 5(2), 15-22.

Sahupala, A. 2010. Pengaruh Suhu dan Lama Penyimpanan Terhadap Viabilitas Benih Merbau (Intsia bijuga, OK). Jurnal Agroforestri, V(4).

Sari, W. \& Faisal, M. F. (2017). Pengaruh Media Penyimpanan Benih Terhadap Viabilitas dan Vigor Benih Padi Pandan Wangi. Agroscience, 7(2), 300-310.

Solikin. (2014). Pengaruh Lama Penyimpanan Terhadap Perkecambahan Biji Stachytarpheta jamaicensis (L.) Vahl.. Berita Biologi, 13(1), 65-70.

Suita, E. (2013) Pengaruh Wadah, Ruang dan Periode Simpan Terhadap Viabilitas Benih Kilemo (Litsea cubeba Persoon L.), Bogor: Balai Penelitian Teknologi Perbenihan Tanaman Hutan.

Suryanto, H. (2013). Pengaruh Beberapa Perlakuan Penyimpanan Terhadap Perkecambahan Benih Suren (Toona sureni). Jurnal Penelitian Kehutanan Wallacea, 2(1), 26-40.

Tjandrawinata, R. R., Nofiarny, D. \& Susanto, L. W. (2017). The use of Phyllanthus niruri L. as an Immunomodulator for The Treatment of Infectious Diseases in Clinical Settings. Asian Pacific Journal of Tropical Disease, 7(3), 132-140.

Wahjuni, S. (2017). Ekstrak Daun Meniran (Phyllanthus niruri. L) Memperbaiki Kerusakan Sel- $\beta$ Pankreas dan Menurunkan Kadar Gula Darah Tikus Wistar Hiperglikemia Diinduksi Aloksan. Intisari Sains Medika, 8(2), 160-163.

Widiyastuti, Y. et al. (2012). Vademekum Tanaman Obat untuk Saintifikasi Jamu Jilid 1 (Edisi Revisi ). Jakarta: Badan Penelitian dan Pengembangan Kesehatan.

Widodo, H., Listyana, N. H. \& Widyastuti, R. (2010). Studi Umur Simpan, Suhu dan Cahaya Terhadap Daya Perkecambahan Benih Artemisia annua L. Jurnal Tanaman Obat Indonesia, 3(1), 1-8.

Yuniarti, N. \& Djaman, D. F. (2015). Teknik pengemasan yang tepat untuk mempertahankan viabilitas benih bakau (Rhizophora apiculata) selama penyimpanan. Surakarta, Fakultas MIPA Universitas Sebelas Maret, 1438-1441. 